\title{
Copyright in Unpublished Works: 2039 and Orphan Works
}

\author{
Aislinn O'Connell
}

\begin{abstract}
Transitional provisions in the implementation of the Copyright, Designs and Patents Act (1988) made changes to the copyright protection to works which were unpublished at the time of the implementation of the Act. Those unpublished works will remain in copyright until 31 December 2039, rather than in perpetuity, as was previously the case. Following a consultation in late December 2014, the government has stated that they will not be making any changes to the legislation until further discussions take place. This article discusses the ways in which cultural and heritage institutions may make use of works subject to the 2039 rule, including both UK and European Orphan Works provisions, and considers the possible solutions for making the use of older 2039 works simpler.
\end{abstract}

\section{Introduction}

The implementation of the Copyright, Designs and Patents Act (CDPA) (1988) was a major reform of copyright law in the UK. The Act fundamentally changed when the copyright 'clock' starts ticking, fixing it at the point of recording (whether in writing or otherwise), rather than at the point of publication. Where previously unpublished works could remain in copyright in perpetuity (Copyright Act 1956, s 2(3)), the 1988 Act introduced transitional provisions which fixed a fifty-year copyright on all literary, dramatic, musical works, engravings, and photographs which remained unpublished at the end of the year in which the Act came into force (which was 1989) (Schedule 1, Para 12, CDPA, 1988). This meant that works not yet published on 31 December 1989 will remain in copyright until the end of 2039 - regardless of when the work was originally created. This applies only to works by authors who died prior to the 1 August 1969 , and where the work is not anonymous or pseudonymous - different provisions apply in those cases. This contrasts against the new copyright term introduced by the Act, which stated that copyright arose at creation and generally lasted for fifty years after the death of the author (s 12(1) CDPA (as enacted)).

\section{Author}

Aislinn O'Connell is a PhD candidate at the Department of Information Studies at University College London.

Email: aislinn.oconnell.12@ucl.ac.uk.

Received 20 May 2015

Accepted 12 December 2015 
The duration of copyright after the death of the author (post mortem auctoris (PMA)) was further extended in 1996 to 70 years (Duration of Copyright and Rights in Performances Regulations 1995, SI 3297).

This fifty-year copyright term granted by the CDPA transitional provisions matches the term that would have been granted to any work that had been published at that point. This was to ensure that works which would have been in copyright had the Act not been introduced would not be left without copyright protection terms by virtue of the change in copyright regime.

However, this has led to a huge number of old works failing to fall into the public domain. The Imperial War Museum estimates that almost all of their 1.75 million works are unpublished, with a substantial proportion of those falling under the 2039 rule (IPO, 2015a, 2). The term of protection for 2039 works, regardless of whether they were 26 or 206 years old in 1989, remains the same, with 24 years still to run until the expiration of the 2039 provisions.

In addition to the fact that these works are protected by copyright despite their age, the fact that they are so old often means that the knowledge of their copyright holders has been lost, making them both 2039 works and orphan works - works for which the copyright holder cannot be found. Given that the chain of ownership may have passed down over hundreds of years, tracing it could be nigh on impossible. This article considers the developments for 2039 works from late 2014 to early 2015, and considers the possible avenues for using those works in the future.

This is not to say, of course, that the problem of 2039 and orphan works is a new or even a recent one. In fact, there has been much discussion of orphan works in the years preceding 2013. Several submissions by heritage institutions to the 2011 Hargreaves consultation on intellectual property mentioned the issues of 2039 and orphan works (Libraries and Archives Copyright Alliance, 2011; National Library of Scotland, 2011; National Library of Wales, 2011; The National Archives, 2011) and the Jisc report, In From The Cold, pointed to the long copyright term as an inevitable cause of works becoming orphans - rights holders are nigh on impossible to trace over such long periods of time (Jisc, 2009, 9).

\section{Government Actions}

In 2013, Parliament implemented the Enterprise and Regulatory Reform Act which, among other things, approved powers to remove some of the complex transitional provisions for 2039 works (ERR Act, 2013). These powers would then have to be implemented via secondary legislation, in the form of Regulations (s 76 ERR Act, 2013). In late 2014, the Government opened a consultation on the possible ramifications of using those powers, specifically s 76 of the ERR Act. The consultation was open for six weeks, from 31 October to 13 December of 2014, and received 43 responses. The majority of these responses were from cultural and heritage institutions (CHIs) citing the difficulty of rights clearances for works subject to the CDPA transitional provisions. In 2014, the centenary of the beginning of World War I, CILIP, the Chartered Institute of Library and Information Professionals, launched a campaign to "free our history", stating that diaries and other personal materials, because they were unpublished at the 
transition date, remain copyrighted despite it being in some cases more than a hundred years since the death of the author (CILIP, 2015) and they were thus unable to display those works. The campaign was backed by multiple museums and libraries, including Collections Trust; Imperial War Museums; International Association of Music Libraries, Archives and Documentation Centres (UK and Ireland); Libraries and Archives Copyright Alliance; National Library of Scotland; Scottish Council on Archives; UCL Library and the University of Leeds (CILIP, 2015). The transitional provisions of the CDPA require lengthy rights clearance processes, involving finding out the author, their date of death, the publication status of the work, and the current copyright holder which, according to a 2010 study for the European Commission, can often be more time consuming and expensive than the digitisation process itself (Vuopola, 2010, 12-14). For those institutions which may hold large numbers of works which need rights clearances (the Imperial War Museum, for example, holds 1.75 million such items (CILIP, 2015)) this can be burdensome.

In a tangentially-related development, in 2014 two sets of Regulations were implemented by the government concerning two orphan works schemes. The first of these, which was enacted under the power granted by the Enterprise and Regulatory Reform Act 2013, is the UK Intellectual Property Organisation (IPO) licensing scheme, which allows the granting of licences for commercial and noncommercial use of orphan works (ERR Act, 2013, s.77). The second, which is allowed under Directive 2012/28/EU of the European Parliament and of the Council on certain permitted uses of orphan works (2012) is the EU orphan works scheme, which allows cultural and heritage institutions to use orphan works in certain limited ways (Copyright and Rights in Performances (Certain Permitted Uses of Orphan Works) Regulations (SI 2861), 2014; Copyright and Rights in Performances (Licensing of Orphan Works) Regulations (SI 2863), 2014).

Lastly, a variety of copyright exceptions were introduced in 2014, most relevant among which was the exception created by the Copyright and Rights in Performances (Research, Education, Libraries and Archives) Regulations 2014. This allows libraries, museums, educational establishments and archives to create copies of works for preservation purposes (s42(1) CDPA, 1988) and to allow access to works at dedicated terminals on-site (s40B CDPA 1988). These exceptions have broadened the activities available to libraries and archives, and apply to all copyrighted works, which includes 2039 and orphan works (SI 1372, 2014).

\section{Results of Consultation}

The governmental response to the consultation stated that it had decided not to take further action at the time, but would seek further information from interested parties (IPO, 2015a). It backed up this decision not to take further action by stating that certain rights holders have built their business models on the expectation that their copyright will last until 2039. A primary example is that of the Ralph Vaughan Williams Charitable Trust, which administers the copyright on Williams' works, and uses the revenue licensing these works to support British composers and support further performances of those works. Changing the date at which Williams' works will fall into the public domain (on a 70 years PMA 
interpretation this would be 11 years earlier than 2039) would negatively affect the revenue stream of this trust.

The response further pointed out that an additional submission stated that allowing works which have not yet been published to fall into the public domain may be damaging to legitimate rights holders, as they would lose out on any potential licence fees for their works, which rights holders would at present be able to accrue if someone wished to publish the works at some point in the next 24 years. Further, several contributors, especially those representing authors and rights holders, suggested that the removal of property from legitimate rights holders could be considered a violation of human rights, and thus problematic for the UK Government (IPO, 2015a, 4).

For these reasons, the government decided not to take any action to use the ERR powers until further investigations had been made. The IPO pointed to the newlyimplemented orphan works licensing system and also to the creation in 2014 of the libraries, archives and museums exception to copyright, which allows a range of activities including preservation and archiving, as well as digital access at dedicated terminals on the premises, for the purposes of research and private study (IPO, 2015a).

Although the consultation did not result in any promises to change the 2039 legislation - in fact it specifically stated that there was no intention to utilise the powers to change the system without further consultation - there has been an improvement to the situation for CHIs. One of the major difficulties with 2039 works was that they could not be displayed in museums and archives, due to a provision of the CDPA, which stated that copyrighted works may not be "performed" in public without the permission of the rights holder. It then goes on to specifically state that it includes "any mode of visual or acoustic presentation" (s 19(2)(b) CDPA, 1988). Interpretation of this section was contested; it was unclear whether or not display would constitute performance of a work. In March 2015, the Intellectual Property Office published a copyright notice which stated that the display of items such as letters or diaries does not violate the copyright of those items (IPO, 2015b), as it does not constitute a performance in the same way that a performance of a musical or video work would. This then avoids the issue faced by many libraries and museums at the centenary of the beginning of WWI, as the notice clarified that they would be able to display such items as personal letters or diaries without infringing copyright. While IPO copyright notices are not legally binding, they are generally taken as a statement of official thinking on a particular topic, and thus a good indicator of the permissibility of certain acts. This in turn eliminated the main campaign pressure of the \#catch2039 movement, which used the display of blank letters as a talking point to highlight their previous inability to display such works.

\section{Solutions for using 2039 and orphan works}

From the government response to the 2039 consultation, there are five potential ways to make use of a 2039 work. The first steps in making use of a 2039 work are the same regardless of which method is used in the end. First, an attempt must be made to establish the author and the age of the work. The method of 
establishing the author is, of course, dependent on the work itself. Personal letters and diaries might have the author name inscribed upon them, a starting point for searching out their descendants and the current rights holders. Photographs and other artistic works may have been registered in photographic societies, or marked in some way by the author. It is a process individual to each work. The date of creation of the work may be similarly difficult to ascertain; if it is marked upon the work, then that is relatively simple, but one might also take into account the possibility of dating pictures or photographs using more technical methods.

As well as establishing if possible the identity of the author, and their date of death, it is also necessary to establish whether or not the work has been published, and if so, whether this was prior to 31 December 1989. It is, of course, only if the work remained unpublished at that date that it falls under the 2039 provisions. For CHIs that keep meticulous records, it may be a matter of simply checking the records to ascertain the publication status of a work prior to 1989, but this is an ideal situation, and certainly not one which will apply to all works.

It is at the point that the copyright holder has been ascertained that the possible paths diverge. If it is not possible to establish the author of the work after a diligent search, then it is classed as an orphan work (although it may well also be a 2039 work).What constitutes a "diligent search" may differ, depending on who is requiring the search. The IPO licensing scheme gives guidelines on diligent searches, according to the type of work (IPO, 2014), and requires applicants for licences to complete a list of registries and databases that they have searched. The IPO provides checklist(s) for completion, which are required to be uploaded as part of the licensing process. The EU Directive, on the other hand, does not have a strict requirement to fulfil: applicants are required to self-certify that they have completed a diligent search. After the search is complete, if the rights holder for the work cannot be found, then the work is an orphan, and thus options 1, 3, 4 and 5 are open to the CHIs for use of the work. If the rights holder has been established, then only options 1,2 and 3 are available.

\subsection{Option 1: display only}

This option, following the guidance given by the IPO in March of 2015 (IPO 2015b), allows CHIs to display works which are still in-copyright, regardless of whether or not the copyright holder can be found. This is especially helpful for museums and archives that may wish to display, for example, letters or diaries of soldiers who fought in World War I. The display of such works does not fall under the definition of a "performance, showing or playing" as required by the legislation. This guidance from the IPO largely eliminates the issues faced by many archives and museums in their "free our history" campaign, giving them more certainty in the matter of displaying works. This is not to say that a rights holder would not be able to bring an infringement case against a $\mathrm{CHI}$, but in the IPO's opinion, such display is not infringing.

\subsection{Option 2: obtaining licences}

A second option available to any interested party is to obtain a licence. The feasibility of this depends on the individual rights holder in each specific case. There are of course potential difficulties in identifying or contacting the rights 
holders. Once they have been identified, those who hold a number of copyrighted works and who have a functional licensing system in place may offer a relatively simple process for providing licences. Some rights holders for certain 2039 works do have effective systems in place, such as the Vaughan Williams Trust which licences the unpublished works of British composer Ralph Vaughan Williams. However, given that this discussion centres on unpublished works, this may be unlikely. It is possible that people may not be aware that they are the rights holder of a particular work, and thus obtaining a licence from them may be difficult or even impossible, as they may have no experience of or desire to engage in the (often complex) process of licensing work.

\subsection{Option 3: relying on the libraries exception}

The third potential avenue to use in order to make use of 2039 works is to rely on the Copyright and Rights in Performances (Research, Education, Libraries and Archives) Regulations 2014 (SI 1372, 2014). This exception to copyright applies to libraries, archives, museums and educational establishments, regardless of whether or not they are for-profit. The exception has several parts, each of which allows a different use of copyrighted works. Institutions may digitise works for preservation purposes (s 42); make recordings of works available at dedicated terminals on the premises (s 40B); supply a copy of a work to another library (s 41); provide a single copy of works (both published and unpublished) for research and private study purposes (ss 42A, 43); and make a recording of a work for archiving purposes, even if the archive is not connected to the maker of the work (s 75) (CDPA, 1988). This range of activities provides additional freedoms to cultural and heritage institutions, and applies to all works (not just 2039 or orphan works), subject to certain limitations, including the reasonable availability of replacement works, and provision of a declaration that another copy of the work has not been made.

While these new freedoms granted by the exception are heartening, there are still substantial restrictions on what libraries, museums and archives may do with works, especially orphan works, and the new exceptions are mostly aimed at maintaining the status quo of collections, such as ensuring that copies are not lost due to age-related deterioration, rather than allowing new methods of access through digitisation and online access. The preservation and digitisation of works, for example, applies only to items in the permanent collection, and must be for reference purposes only. It is still a very narrow exception.

Relying on this exception allows libraries, archives, museums and educational establishments to copy works in order to maintain the integrity of their collection, and also to provide access to works for individuals for the purposes of research and private study. The exception is narrowly framed, however, and only allows one copy to be made for most purposes, thus limiting the activities of CHIs in certain circumstances. 


\subsection{Option 4: IPO orphan works licensing scheme}

As the government's response to their consultation stated, the orphan works licensing process was its suggested forum for allowing use of 2039 works for which the rights holder or holders cannot be found (IPO 2015a, 1). This process is relatively lengthy, as it requires a "diligent search" to be conducted, and the IPO provides a list of organisations which must be contacted in order to attempt this. After the diligent search has been conducted, the system can then be used to indicate:

- the work for which a licence is required;

- the purposes for which it will be used;

- the number of works which will be produced;

- the length of the licence (up to seven years).

This licence restriction may cause issues for those who wish to use the work for longer, especially publishers or for online use. There is a fee for each licence, from a minimum of 10p for non-commercial use upwards, combined with an administration fee of $£ 20$. There is a sliding scale of fees, depending on the number of works requested. As documented by Terras (2014), this process is not yet perfect. In attempting to obtain a licence for a lantern slide, which did not fall into any of the categories prescribed by the IPO, she had some difficulty and was presented with a list of irrelevant organisations to contact in the course of her diligent search. As of the end of April 2015, 263 orphan works had been subject to application, with 220 licences granted (IPO, 2015c). Of these licences, 188 were obtained by the Museum of the Order of St John for still images depicting St John's Ambulance volunteers during WWI. The separate licensing of still images is a deliberate provision of the scheme, in order to reassure rights owners. Further guidance is available from the IPO (IPO, 2013). This demonstrates that it is possible for museums to obtain licences for orphan works, but at a cost, both in terms of time and licence costs. Furthermore, given the huge proportion of orphan works which were licensed by a single institution, the number of different institutions, bodies, or indeed individuals, licensing orphan works is much smaller than the number of licences granted would seem to indicate. There are still problems with the orphan works licensing scheme, including the length of time required to obtain licences (Terras, 2014), and their expiration after a maximum of seven years. The time-limited nature of the scheme leads to difficulties in using orphan works in published form or online, due to the fact that the use would be likely to exceed the duration of the licence. Nonetheless, the IPO orphan works licensing system is still gaining users since its implementation, particularly as it allows the licensing of standalone artistic works.

\subsection{Option 5: European orphan works directive}

There is a second orphan works scheme which applies to Cultural and Heritage Institutions (CHIs) including museums, libraries and archives, which is substantially easier and less restrictive to use. However, it applies only in certain limited circumstances and to specific categories of works. Directive 2012/28/EU of the European Parliament and of the Council on Certain Permitted Uses of 
Orphan Works (2012) was partially implemented into UK law through the Copyright and Rights in Performances (Certain Permitted Uses of Orphan Works) Regulations (SI 2861) (2014) and creates an exception to copyright legislation for certain uses of some types of orphan work by cultural and heritage institutions.

This exception allows archives, libraries, museums, educational establishments, and public service broadcasters to make certain use of orphan works without the need to obtain a licence from the IPO. Those uses include making the work available to the public, or reproducing the orphan work for the purposes of digitisation, making available online, indexing, cataloguing, preservation or restoration (s 42 CDPA 1988). The requirement for a diligent search is still present, but it is self-certified. The exception does not apply to all creative works: it covers literary works, cinematographic works, audio-visual works and sound recordings across the EU, but does not include standalone artistic works like photographs, maps, plans and drawings. It does specifically apply to unpublished works, meaning that it can apply to 2039 works, but even this is a limited inclusion, as it is only applicable to those unpublished works which have been "made publicly accessible by a relevant body" (Schedule ZA1 s 2(3)(c) SI 2861). In this context, a "relevant body" is a CHI which is able to make use of the exception. Given that the "free our history" campaign focused on making publicly held but inaccessible works more freely available, it is likely that a proportion of the works which they sought to free would not fall under the ambit of this scheme.

This scheme does have some limitations. As mentioned above, it applies only to certain categories of works, and excludes maps and photographs. This exclusion is due to be revisited in October of 2015 (Article 10, Directive 2012/28/EU, 2012). Furthermore, it is possible to lose the benefit of the exception if the work is used for purposes outside of the CHI's public interest mission. For the protection of copyright holders, there is a requirement to pay fair compensation for the use of the work if the copyright holder does appear.

\section{Comparison of orphan works schemes}

We can compare the two orphan works systems, IPO licensing and EU exception on several dimensions (Table 1).

The requirement for a diligent search is present in both schemes, although it is more stringent in the IPO licensing system. The EU scheme does not require a monetary fee, whereas the IPO does. However, both schemes will still incur the cost of a diligent search. In the event of a rights holder wishing to claim backdated licensing fees, these can be claimed from the IPO if that system was used, whereas a CHI relying on the EU system will be required to pay licence fees directly to the rights holder. The EU system has more limitations in terms of works, uses, and users. The IPO system is only applicable in the UK, whereas the exception is valid across the EU. Furthermore, works which have been designated as orphans in one European member state hold the same status in other states, giving CHIs a greater body of works which they can use online. Thus, we can see that there are advantages and disadvantages to both the Orphan Works licensing scheme and the European Orphan Works Exception, and the choice of which to use is one which must be made on a case-by-case basis, depending on the work, 
the use to which it will be put and the body which wishes to make use of the work, as well as financial and time considerations.

\begin{tabular}{|c|c|c|}
\hline & IPO Licence Scheme & $\begin{array}{l}\text { European Orphan } \\
\text { Works Directive }\end{array}$ \\
\hline Who Can Use It? & Anyone & $\begin{array}{l}\text { Cultural and Heritage } \\
\text { Institutions }\end{array}$ \\
\hline $\begin{array}{l}\text { What works does it } \\
\text { apply to? }\end{array}$ & All works & $\begin{array}{l}\text { Text based works, } \\
\text { embedded artistic works, } \\
\text { and audio visual works } \\
\text { which have been } \\
\text { published or made } \\
\text { publicly available by a } \\
\text { relevant body. }\end{array}$ \\
\hline $\begin{array}{l}\text { What uses are } \\
\text { covered? }\end{array}$ & All uses & $\begin{array}{l}\text { Making available and } \\
\text { reproductions for the } \\
\text { purposes of digitisation, } \\
\text { making available, } \\
\text { indexing, cataloguing, } \\
\text { preservation or } \\
\text { restoration. }\end{array}$ \\
\hline Diligent Search? & $\begin{array}{l}\text { Yes, with guidance and } \\
\text { specific forms }\end{array}$ & Yes, self-certified \\
\hline Fee Applicable? & $\begin{array}{l}\text { Yes, minimum } £ 20 \\
\text { application fee, plus } \\
\text { minimum 10p licence } \\
\text { fee }\end{array}$ & No \\
\hline $\begin{array}{l}\text { Rights holder claims } \\
\text { covered? }\end{array}$ & $\begin{array}{l}\text { Yes, the IPO will pay } \\
\text { licence fees }\end{array}$ & $\begin{array}{l}\text { No, the user must pay } \\
\text { licence fees }\end{array}$ \\
\hline Duration? & Up to seven years & $\begin{array}{l}\text { Until copyright expires, } \\
\text { or until the rights holder } \\
\text { appears }\end{array}$ \\
\hline Area covered & UK Only & EU-wide \\
\hline
\end{tabular}

Table 1: comparison of orphan works schemes.

There are also further concerns that certain works licensed under the Orphan Works Scheme may not, in fact, be orphan works, but might be public domain works. Where the original rights holder cannot be found, it is then difficult to establish what their date of death was, or the publication status of their work, and thus institutions and individuals who purchase orphan works licences may be doing so unnecessarily (Korn, 2015). 


\section{Possible future solutions}

Although there are now several options in place for organisations to use 2039 and orphan works, there are still reasons to reduce the number of works which fall under the 2039 provisions, or indeed removing them altogether. Currently the UK is the only country in Europe which has such provisions. It is unique among the member states in that some of its historic works are not available for use without a licence, whether from the IPO or the rights holder.

The interaction of this unique UK situation with the dissimilar wider European situation is potentially interesting. It means that UK works are not permitted to fall into the public domain in the same way as other European works. This then hampers international cooperation in terms of research and use of older artistic works, as works which are in the public domain in other member states give much more freedom with regard to uses than their UK counterparts. These extra restrictions on UK works impede the general movement in European copyright towards harmonisation, leaving the UK out of step with other member states. The UK would struggle to participate in a project which collected or compared diaries of WWI soldiers, for example, as these would be 2039 works, and often also orphans, where equivalent documents would be public domain in other EU states.

We can see from the above discussion that there are solutions available to obtain licences or permission to display and reproduce 2039 and orphan works (or works which fall into both of those categories). This disparity between the UK and other European member states is not the only area in which copyright diverges (indeed, there are many) but it is one which throws up particular obstacles to using historical creative materials.

Display of private communications, such as letters and diary entries is, according to the IPO's copyright notice, not a violation of copyright. Further, the reproduction of works such as 2039 works is permissible under the orphan works exception for CHIs, provided that it is for one of the above specified purposes. Lastly, if an institution wishes to use an orphan or 2039 work for purposes above and beyond that permitted by the European exception, they may apply to the IPO for an orphan works licence, which lasts for seven years, with an option to renew.

However, for works which may be hundreds of years old, a subsisting copyright which will continue to exist for the next 24 years is a stringent protection. It means that there are still many procedures to go through before the works can be used, and there are restrictions on the ways in which they can be used. Thus, although the UK government has committed to not utilising the powers laid out in the ERR Act without further consultation, there are several options open to the UK government which should be explored in order to allow greater use of 2039 and orphan works.

Option 1: Use the powers in the ERR Act 2013 to change the copyright protection of still unpublished 2039 works to match the standard term, which is the life of the author plus 70 years.

This solution would have the following effects: 
- Already published works would remain unaffected by the change (for example, those of the Vaughan Williams Trust);

- The vast majority of historical 2039 works would move into the public domain;

- This would allow greater freedom to use those historical works;

- Given that 2039 status only applies to works by authors deceased prior to 1 August 1969, no copyright terms would be extended;

- Ascertaining publication status would no longer be a consideration when conducting assessment of potentially orphan works;

- The UK would no longer have a disparity against other EU Member States regarding copyright in unpublished works.

There are issues which would need to be considered before the possible implementation of this scheme. The underlying human rights issues which stayed the hand of the government in response to the consultation must be carefully considered and any issues resolved before copyright terms are changed. These specifically include rights relating to the removal of property (IPO, 2015a, 4). Thus, it would not be possible to implement this solution without preliminary human rights research and an evaluation of the implications of this.

Option 2: Use the powers of the ERR Act to extinguish copyright in those unpublished works which pre-date the $20^{\text {th }}$ century, with the following effects:

- All still unpublished 2039 works from before 1900 would move into the public domain;

- 2039 works which have already been published would be unaffected by this change;

- Historic works would be freed up for greater uses;

- Some 2039 works would continue to exist, namely those works created between 1900-1989;

- Thus, this would not solve the problem of 2039 works, but could reduce it;

- Ancient, medieval, and pre-20 $0^{\text {th }}$ century works would all be freed up for use by falling into the public domain;

- The UK would be more in line with other EU member states, with the exception of those works created from 1900-1989.

This option raises the same issues of human rights that are raised by option 1, and thus robust and authoritative research would be an absolute necessity before implementation. Furthermore, this option still leaves ninety years of unpublished works unaccounted for and subject to the 2039 rule, and thus does not solve the problem, only ameliorate it. The disadvantage of this may be that those works would remain unusable for the remaining 24 years of the 2039 term, and the burden of ascertaining publication status would remain on those who wish to those works, together with the diligent search requirements of orphan works schemes. Furthermore, it is impossible to know the proportion of 2039 works 
which would be affected by this change, and a further difficulty would arise for those works which were created around the turn of the century, in that it would be crucial to establish their exact date of creation, in order to know whether or not the 2039 rule would still apply to those works.

Option 3: Maintain the status quo.

- The options for using orphan and 2039 works discussed above would remain available;

- No additional human rights concerns would have to be investigated;

- Many 2039 works would remain essentially inaccessible for another 25 years.

Although there are some concerns with removing the copyright from older works, including human rights issues, it is important to note that the vast majority of 2039 works, due to their venerable age, do not have traceable rights holders, which may limit potential violation of human rights. However, this would need to be evaluated by an Impact Assessment from the UK government which ascertains the level of potential damage from such a move. The solutions discussed above could be modified in order to avoid violating the human rights of any copyright holder, subject to further research.

Furthermore, the application of the standard term or reduced terms to 2039 works does not necessarily mean that those works would have no rights attached to them whatsoever. There is a right analogous to copyright, known as the publication right, which creates copyright-like property rights for unpublished works that have fallen into the public domain (Copyright and Related Rights Regulations (SI 2967), 1996). This grants the first publisher of a work a 25 -year monopoly over the further publication and dissemination of a particular creative work. However, there is nothing to say that the first publisher of a work must be the author, or the prior holder of the (now-expired) copyright, and thus this right would not automatically be assigned to previous copyright holders. Thus, a third party could publish a previously unpublished 2039 work, and benefit from the publication right for the following 25 years, while the holder of the (now extinct) copyright would no longer have any rights over the work.

This scenario would result in the extinguishing of copyright which was due to run until 2039. That expired copyright could be supplemented by rights holders simply publishing the works in which they hold the rights first, meaning that the publishing right would accrue to them, and not to a third party. Ideally, they would do this before the expiration of their copyright, as until their copyright expires, they have the exclusive right to do so. If this does not occur before they fall into the public domain, however, the nature of the publication right could lead to a race to be the first to publish, which would lead to sub-standard editions being produced in order to obtain the publication right, at the expense of better editions which took more time to publish by virtue of their superior publishing quality (IPO, 2015a). This same race could occur in 2040, with a greater number of works, as the (almost unknowable) entirety of works subject to the 2039 rule fall into the public domain. 
The number of 2039 works is unknown, and difficult to accurately estimate. Publishing or utilising them is difficult and time-consuming, especially where they are also orphan works. Allowing more 2039 works to fall into the public domain is a simple step which would free up more copyright works for display and use by cultural and heritage institutions without damaging the legitimate business models which rely on the use of works which have been published in the almost 30 year period since the implementation of the CDPA 1988. It would further greatly reduce the number of hours required for rights clearances, not only from cultural and heritage institutions, but for all bona fide users of copyright works. Furthermore, applying the standard term to still unpublished 2039 works would eliminate the difficult and time consuming processes which set 2039 works apart from other creative works, and those in other EU member states. The movement towards allowing the use of orphan works in Europe and in the UK is one which has been supported by research in the form of the European Green Paper (European Commission, 2008), which points out that while there is demand to use orphan works, their very nature as orphan works means that there are no rights holders attempting to exploit the copyright in the works, meaning that they are left unable to be used. This was the rationale behind the Orphan Works Directive, and a similar rationale can be applied to still unexploited 2039 works. The majority of 2039 works are orphans, and those that are not orphaned have generally been exploited for commercial gain already. Thus, it is difficult to see where the detriment in freeing up 2039 works can be found.

While the IPO is undoubtedly aware of the arguments both for and against freeing up 2039 works, and elected in this instance not to implement a change to copyright duration, this may be because the consultation did not distinguish between subsequently published 2039 works and still unpublished works. Thus, with the considerations of rights owners submitted to the Consultation, further consideration would be required before implementing a new exception or a change to copyright law. The distinction between 2039 works which are being exploited and those which are lying unused and unusable is something which could be explored by the government's seeking further views, as mentioned in the response to the consultation (IPO, 2015a, 1).

\section{Conclusion}

Although the government consultation on 2039 works stated that the government would not immediately use the powers created by the ERR Act to reduce the copyright duration in 2039 works, there is every reason for the government to continue to explore more avenues which will free up unusable 2039 works for use by the greater public. This is indicated by the response to the consultation document, which stated that the government would not take further action "at this time" but would "seek further views" (IPO, 2015a, 1). However, it is clear that some 2039 works are already being exploited to their full potential, and thus it would be unwise to remove this potential from rights holders. Therefore, the government should shift its focus to concentrate not on 2039 works which are being exploited, but on those that still remain unpublished and unusable.

The developments of the last number of years, especially with regard to orphan works licensing and the clarification regarding the display of copyrighted material 
are important, but it is also vital that the UK continues to develop its copyright regime in order to maintain parity with other European member states, to encourage creativity, to allow the use and distribution of historical creative works and to allow additional creative works to reach a wider audience in the UK. Given the general movement of the EU towards greater harmonisation of copyright rules (indeed, cross-border portability of copyright works is one of the issues considered as part of the EU's Digital Single Market strategy) there is a need for the UK to consider carefully this anomalous copyright provision when seen in the context of the wider European framework.

The development of a system which simplifies the complicated rules regarding 2039 works would lead to greater use of historical creative works, which are often of great cultural and historical interest due to their age and nature. Examples of 2039 works held by CHIs which would become available include the letters of Conan-Doyle, held by the Natural History Museum. These letters are still in copyright due to their unpublished nature, while the rest of his body of work has fallen into the public domain. Similarly, the Tate holds the works of Walter Sickert, Henry Scott Tuke, Gaudier-Brzeska and Thomas Cooper Gotch (CILIP 2014). There is a substantial argument to say that enabling these works to make their way into the world would enhance the cultural, artistic, and historical offerings of CHIs, rather than locking away interesting and artistic works to remain unused and largely ignored for a further two and a half decades. Not only this, but it would also reduce the number of hours required by cultural and heritage institutions for work on clearing rights, and should reduce the financial costs associated with using such works. The unique situation of the UK amongst EU member states could be framed as an advantageous protection of rights holders, but in reality, those rights holders willing to exploit their 2039 works are already doing so, and the implementation of carefully considered provisions to enable use of currently unusable 2039 works would bring manifold benefits to the British public, research, culture, and heritage.

\section{References}

CILIP (2015) Free Our History [online]. URL:

http://www.cilip.org.uk/cilip/advocacy-campaigns-awards/advocacycampaigns/copyright/free-our-history [accessed 17.05.15].

CILIP (2014) Briefing about copyright terms for published and unpublished works [online]. URL:

http://www.cilip.org.uk/sites/default/files/documents/Briefing\%20about\%20copyr ight $\% 20$ terms $\% 20$ for $\% 20$ published $\% 20$ and $\% 20$ unpublished $\% 20$ works $\% 20$ Octob er\%202014.pdf [accessed 18.11.15]

Copyright Act (1956) (c.74) London: The Stationery Office.

Copyright, Designs and Patents Act (1988) (c.48) London: The Stationery Office.

Copyright and Related Rights Regulations (1996) (SI 1996/2967). London: The Stationery Office.

Copyright and Rights in Performances (Research, Education, Libraries and Archives) Regulations (2014). London: The Stationery Office. 
Copyright and Rights in Performances (Certain Permitted Uses of Orphan Works) Regulations (2014) (SI 2014/2861). London: The Stationery Office.

Copyright and Rights in Performances (Licensing of Orphan Works) Regulations (2014) (SI 2014/2863). London: The Stationery Office.

Copyright and Rights in Performances (Research, Education, Libraries and Archives) Regulations (2014) (SI 2014/1372). London: The Stationery Office.

Directive 2012/28/EU of the European Parliament and of the Council of 25 October 2012 on certain permitted uses of orphan works (2012) Strasbourg: European Parliament.

Duration of Copyright and Rights in Performances Regulations (1995) (SI 3297) London: The Stationery Office.

Enterprise and Regulatory Reform Act (2013) (c.24) London: The Stationery Office.

European Commission (2008) Green Paper: Copyright in the Knowledge Economy [online]. URL:

http://ec.europa.eu/internal_market/copyright/docs/copyrightinfso/greenpaper en.pdf [accessed 31.08.2015].

IPO (2013) UK Orphan Works Licensing and the EU Directive on Orphan Works [online]. URL:

http://webarchive.nationalarchives.gov.uk/20140603093549/http://www.ipo.gov.u k/hargreaves-orphanmyth.pdf [accessed 26.08.15]

IPO (2014) Guidance: Orphan Works Diligent Search Guidance for Applicants [online]. URL: https://www.gov.uk/government/publications/orphan-worksdiligent-search-guidance-for-applicants [accessed 26.08.15]

IPO (2015a) Government response to the consultation on reducing the duration of copyright in certain unpublished works [online]. URL:

https://www.gov.uk/government/uploads/system/uploads/attachment_data/file/399 171/973 - Governement Response -

_copyright_in_certain_unpublished_works.pdf [accessed 17.05.15].

IPO (2015b) Copyright Notice: public exhibition of copyright works Copyright Notice Number: 5/2015 [online]. URL:

https://www.gov.uk/government/uploads/system/uploads/attachment_data/file/415 698/Copyright Notice - 52015 exhibition of works.pdf[accessed 17.05.15].

IPO (2015c) Orphan Works Register [online]. URL:

https://www.orphanworkslicensing.service.gov.uk/view-register [accessed 17.05.15].

Jisc (2009) In From The Cold: An Assessment of the Scope of 'Orphan Works' and its Impact on the Delivery of Services to the Public [online]. URL:

http://www.webarchive.org.uk/wayback/archive/20140615221324/http://www.jisc .ac.uk/media/documents/publications/infromthecoldv1.pdf [accessed 20.08.15]. 
Korn, Naomi (2015) When is the Public Domain Not the Public Domain? CILIP Blog [online]. URL: http://www.cilip.org.uk/cilip/blog/when-public-domain-notpublic-domain [accessed 18.05.15].

Libraries and Archives Copyright Alliance (2011) LACA Response to the UK IP Review [online]. URL:

http://webarchive.nationalarchives.gov.uk/20140603093549/http://www.ipo.gov.u k/ipreview-c4e-sub-libraries.pdf [accessed 15.11.2015].

National Archives (2011) Review of Intellectual Property and Growth: Call for evidence on copyright Response to the Call for Evidence by The National Archives [online]. URL:

http://webarchive.nationalarchives.gov.uk/20140603093549/http://www.ipo.gov.u k/ipreview-c4e-sub-thena.pdf [accessed 15.11.2015]

National Library of Scotland (2011) Independent Review of Intellectual Property and Growth: A Response by the National Library of Scotland [online]. URL: http://webarchive.nationalarchives.gov.uk/20140603093549/http://www.ipo.gov.u k/ipreview-c4e-sub-nls.pdf [accessed 15.11.2015]

National Library of Wales (2011) Independent Review of Intellectual Property and Growth: Response Submitted by the National Library of Wales [online]. URL: http://webarchive.nationalarchives.gov.uk/20140603093549/http://www.ipo.gov.u k/ipreview-c4e-sub-nlw.pdf [accessed 15.11.2015]

Terras, M. (2014) Reuse of Digitised Content (4): Chasing an Orphan Work Through the UK's New Copyright Licensing Scheme, Melissa Terras' Blog [online]. URL: http://melissaterras.blogspot.co.uk/2014/10/reuse-of-digitisedcontent-4-chasing.html [accessed 17.05.15].

Vuopola, Anna (2010) Assessment of the Orphan works issue and Costs for Rights Clearance European Commission. URL: http://www.ace-film.eu/wpcontent/uploads/2010/09/Copyright anna report-1.pdf [accessed 20.08.15].

\section{Open access and copyright}

Library and Information Research is an open access journal. A freely available copy of this paper may be downloaded from the journal's website:

http://www.lirgjournal.org.uk.

Copyright and associated moral rights in works published in Library and Information Research are retained by the author(s) but this paper may be used freely, with proper attribution, in educational and other non-commercial settings. 